課題別研究評価

1. 研究課題名： 遷移金属元素を含むIV族クラスタ固体における状態転移と午の応用

2. 研究者氏名：谷垣勝巳

3. 研究の概要

1998年10月一2001年9月の期間、さきが研究21「状態と変革 研究領域で行った研究は、IV 族元素を主成分とする正12面体ナノクラスタ物質にdブロック電子系である磁生元素を導入して、 従来の伝導に加えて磁性か発現する新しいナノクラスタ物質を設計して実際に作り出し、光の物性 を明確にしたことである。本研究て哈成した物質は、dブロック元素であるMnを正12面体クラスタ結 晶の特殊なサイトに導入した新しい磁性クラスタである。この物質では、10Kにキューリ温度を有す る自発磁化に基づく強磁性転移力観測されることが、磁化率測定により明らかにされた。研究で達 成した磁性ナノクラスタ物質の意義は、クラスタネットワークを利用して磁性電子系と伝導電子系を 独立に制御できる可能性を秘媇新しい磁生電子系物質を作りだし、ナノクラスタ物質を用いた物 質開発の方法論における新しい基礎を作った事にある。従って、さきがけ21個人研究で遂行した 本研究は、多面体ナノクラスタ材料において、従来の伝導系ばかりでなく初めて磁生系を導入して、 ナノクラスタを基礎とする次世代新素材への新しい道を開拓したという観点から評価される。

\title{
4. 研究のねらいおよび自己評価
}

近年の物性科学は、物質の極微細構造まて踏み込んで、物性と構造との関係を理解し、光の 理解を基礎として新しい素材を開拓しようとする時代に突入している。この樣な物質科学の発展 はこれまで、リソグラフィー技術を基盤として進められてきた。現在では、電子線加工技術を使用

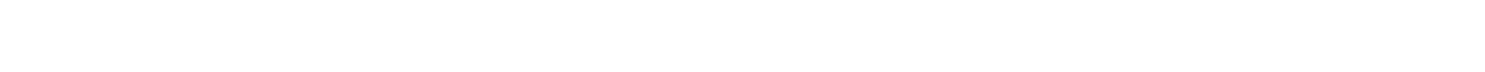
発展により、原子を 1 個ずつ制御する事か河能となつた。しかし、原子を 1 個ずつ並べていたの では、固体物性か観測できる程度の構造体を構筑するためには、半永久的な時間が必要となる。 このような状況において、クラスタは自然か備えている自己形成機能と関係した物質形成機構に より形成されるナノ素材である。従って、ナノ領域のサイズを有するクラスタを基本構成要素とし て創生することのできる結晶固体は、ナノ構造に基づて発現する物性を精密に制御する事の できる新しい物質を設計する舞台を提供する。本研究では、 $\mathrm{N}$ 族クラスタ結晶の特定のサイトに、 磁性電子を有する遷移系列元素を導入した新しい結晶を合成して、ナノ構造に基づいて発現す る磁性現象を探究する事を目的として研究を行った。すなわち、さきが研究 21、状態と変革」 研究領域における本研究テーマは、最近の進歩が著しいクラスタ物質を基本として構成される 結晶において、伝導物性に加えて特異な磁生物性か発現する物質群を開拓して、従来のクラス 各結晶の研究を伝導領域の研究から磁性領域にまたがる研究に展開することを意図した研究で ある。

\section{1 主な研究成果}

磁性ナノクラスタに関する研究の目的は、先に述べたように伝導系と磁性系か相関関係を有す 
る系において、磁性電子系と伝導電子系を独立に制御できる新しいナノクラスタ物質を、クラスタ ネットワークの階層構造を活用して生み出し、ナノクラスタ物質を用いけ新しい物質開拓を行うと共 に、ナノクラスタ物質の次世代新素材への道を開拓することにあった。光のために研究の初期にお いては、I族クラスタ固体と種々の遷移系列元素を組み合わせた結晶相の探索を行った。弚の結 果、正12面体クラスタを結合する結晶サイトか特別なサイトであり、このサイトを制御することによ り目的とする物質系を合成できる可能性がある事を見出した [Phys, Rev. B , 1999。またこの結晶 サイトを利用すると、Si元素とGe元素が混合した正12面体クラスタか安定に存在し、SiとGeが混合 した正12面体クラスタを基本構成要素とする結晶が合成できることを示した。実際にこのような研 究で得られた知見を適用して、N族正12面体ナノクラスタ $(\mathrm{IV})_{20}$ を構成単位とする結晶に磁性元素 を導入した新しいナノ素材を作り出し、ナノクラスタ結晶を従来の伝導領域から磁性領域に発展さ せる事に成功した。本物質は、 dブロック元素であるMnをクラスタ結晶のこの特殊なサイトに導入し た新しいクラスタである[Appl. Phys. Lett., 2000。新しく生み出されたナノクラスタからは、クラス タに内包された元素から供給される伝導電子とクラスタに組み込まれた磁性電子の間の相互作用 に基づくと考えられる興味ある磁性物性か発現し、ナノクラス多物質における新しい展開を拓くもの と考えられる[物理学会誌、最近の研究2001]。

さきかけ研究21の研究期間で行った本研究は、ナノクラスタ物質に対して従来の伝導系ばかり でく、初めて磁生系を導入したという観点で重要である。合成したナノクラスタ磁性体に関する二 連の特許は、2000年 (シリコンおよびゲルマニウム磁牲クラスレート化合物およびとの製造方法： 特願 2000-210850) および2001年 (磁性クラスレート化合物および光の製造方法：特願 2001-186266) と、合計2件提出する事が出来た。

この他に関連研究として、研究プロジェクトの期間中に他のメンバーの方々と共同研究する機 会を持つことができた。第1期の守友浩先生とは、Siラスタ超伝導物質の比熱測定を共同研究し、 超伝導体の対称性を決定することができた。第2期の伊藤公平先生からは30Si同位体元素を分讓 頂き、Siクラスタ超伝導体物質の超伝導同位体効果を測定して、この超伝導体がBCS超伝導体で ある事を確認する事ができた。また、第2期の斗内政吉先生とは、クラスタ系物質に電界効果型卜 ランジスタ素子を適用した超伝導物性の研究を、共同研究として現在進めている。本研究プロジェ クトのテーマ以外に、さきが研究21メンバーの方々と共同研究をすることが出来たことは、私にと って大きな収穫であった。

42 国内外の研究状況・背景と科学技術上の研究の意義

ナノクラスタに関する研究はC 60 ならびにナノチューブを代表とするフラーレンの研究を契機とし て、アルカリ元素クラスタなどを中心とする基礎的な研究の段階から、正多面体構造を基本とする クラスタおよび炎れらのクラスタネットワークを基礎する関連固体の研究へと、発展を続けている。 現在の研究の中心は、ナノ構造制御されたこれらのクラスタ物質を用い、どのような物質設計をす れば将来の新しいエレクトロニクス素材を生み出せるかという点にある。また新しい素材の創製は、 興味深い物性論を含んでいるので基礎科学分野の観点からも重要な研究となっている。最新技術 
である電子トンネル覱微鏡および原子間力覱微鏡などを用いると、原子1個1個を動かすという手 法でオングストローム構造体を作ることか出来る。しかし、この手法ては、物質として有用な大きさ の構造体を作り出すために膨大な時間か溎かってしまし非現実的である。しかし、ナノクラスタ結 晶はある意味、物質形成の環境を整えておけば、セルフアセンブル (自己組織化現象) によりナノ 領域の構造を微細加工せずに形成することか出来る。従って、欠陌の無い高品質のナノ物質を形 成することか出来る。この概念は、ナノ物質を作り出す基本的手法として、世界中て樣々な観点か ら研究されている。产の中でも、鍵を握る重要な物質と考えられているのが、多面体ナノクラスタで ある。

一方、社会·経済の要請として、従来の物質とは異なる新しい物質探索を必要としている。この ような要請に対処することができるのは、これまてのシリコン半導体とは異なる新しい素材の開拓 にある。このような社会の動きは、新しい科学技術を基盤とした社会を模索するものであり、また文 明の進展を優先して無視してきた地球環境污染問題に、真剣に取り組むためでもある。従って新し い概念を用いて、地球上に豊富に存在する無害な元素を使用して環境に優しく従来の素材の機能 を凌駕する素材を研究して作りだすことは極めて重要である。この意味で、地球に豊富て安全性 の高いVV族元素 (C、SiおよびGe) を物質の構成要素としてまず考える事が重要である。本研究は、 IV族元素を中心としたナノクラスタを単位とする物質創製の概念を持ち込み、この要請に相伈い 素材の開拓を進めたものでもある。

このようなナノクラスタに関連した研究は1990年代に世界中て幅広く行われ始め、現在でも研究 の対象として増え続けている。しかし、多面体ナノクラス多結晶において磁生を発現させようとする 研究は、これまて試みられていなかった。本研究は、このような多面体ナノクラスタ物質を磁性領 域に初めて展開した研究であり新規性は高い。

\section{3 自己評価}

さきがけ研究21の期間に提案させて頂いた研究課題目標である「多面体ナノクラスタ物質の磁 性系への発展」は、光の展開の基礎となる物質合成を成功させたことで、成し遂げることか出来た。 しかし研究期間内に、重要であるにもかかわらす幾つかの研究課題を完結させる事が出来ていな い。第1に、クラスタ構造ならびに組成を変化させることにより新しい物質群を探索して産業技術に 結びつけ、ナノクラスタ物質を磁性領域の素材として広く活用していくための研究に着手出来てい ない。第2に二本研究の発展として、光ならびに電場など外部からの影響により磁性か非線形に応答 する興味深い物性が発現する可能性があるが、研究を開始出来ていない。第に、何故この物質 系で強磁性などの磁性現象か現れるのかという機構の本質が末解決の状態て終了している。 の1番目ならびに2番目の課題は、ナノクラスタ磁生材料を次世代の素材として発展させていくため に非常に重要な研究課題である。また基礎物性分野を考えると、磁性発現機構を基礎的な観点か ら詳細に理解するという第3の課題は、極めて重要である。従って、この残された3つの課題を研究 対象として今後押し進めることにより、さきが研究21て達成した成果を大きく進展させる必要が ある。 $f$ 電子系元素としてCeを導入した場合の研究を同時に行ったが、弚の後決定した構造か誤り 
である事が判明した。研究の正確性が欠如していた事を反省している。総合として自己評価すると すれば、70点一80点というところと考えている。

\section{4 研究の今後の課題と光の進め方}

I V族ナノクラスタ物質の最も大きな特徵は、物質構造の階層性にある。この階層性か存在す

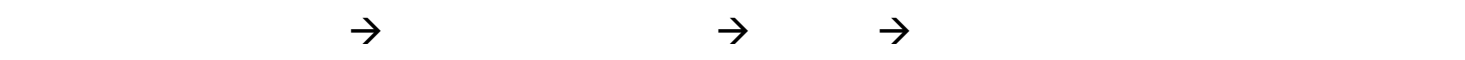
段階て制御できる。従って、物質設計のための種々の物質パラメターを独立に変化させる事が 出来る。本研究の今後の課題は、(1) 本クラスタネットワーク系構造に基づく物質設計の自由度 を活用して、従来の物質設計では困難な電子機能を発現する物質を開拓し、次世代エレクトロニ クスに適用できるナノ磁性物質を開拓すること、(2) 基礎科学分野で重要な話題である、磁性と 超伝導が同時に関係する新しい物質をナノクラスタ物質系に基ついて開拓して、基礎科学の理 解を深めること、でる。ここて椋題(1)は、さきが研究 21 で得られた成果を、更に産業技術分 野で応用の可能性がある素材の探索に結びつける目的研究である。また課題(2)は、ナノクラス 夕結晶の特徵を基礎科学の重要な領域を理解するために、適用しようとする基礎研究である。 (1)に関しては、組成や構成元素を変化させて物質の最適化を図ると共に、光ならびに磁場など の外部摂動に対して高感度に非線形応答する磁性ナノクラスタを探索する。(2)に関しては、クラ スタの階層構造の柔軟性を利用して、種々の基礎物性を測定することで機構を解明したい。

\section{5. 領域総括の見解 :}

籠状構造の原子集合体(クラスタ)を要素とする固体で、クラスタ構造内の特定の部位に種々 の遷移金属を意図的に導入し嗞性体を含む新規機能性物質を実現しようというアイディアが本 研究独自の提案であつた。類似の発想としてロサッカーボール型 660 の固体に各種の不純物を 添加する研究か広く内外て試みられているが、より制御性に富んだ Si Geクラスタに着目したの は口内外でも本研究が最初であるロ 3 年間における研究の進展は予想以上のものであり、数多く の英文原著論文発表により国際的に注目される成果が得られた特に、上記の新規物質に関し ては、2件の特許により実用化の指針が公開されるなど、基礎・応用にわたる広い視野での㧧さき がけ研究 21』の特徵が最大限に活かされた代表的研究の一つと言える。更に、この成果を踏ま えて、基礎・応用の両面で多くの新しい研究計画が展開している。また、本研究領域の研究者 (3 名）との交流により、乥れ光れ相補的発想のもとに共同研究力淮行中であることも特筆に值しよ う。

\section{6. 主な論文等}

1) C. Brown, S. Taga, B. Gogia, K. Kordatos, S. Margadonna, K Prassides, Y. Iwasa and K.

Tanigaki," Structural and Electronic Properties of the Non- Cubic Superconducting Fullerdies A4C60 (A=Ba and Sr)" , Phys. Rev. Letter, 83 (11), pp. 22582261 (1999).

2) Mayumi Kosaka, Katsumi Tanigaki, Kosmass Prassides, Serena Margadonna, Alexandos 
Lappas and Craig Brown, “ Superconductivity in $\mathrm{Li}_{x} \mathrm{CsC}_{60}$ Fullerides” , Phys. Rev. B 59, R6628 (1999).

3) R. F. W. Herrmann, K. Tanigaki, T. Kawaguchi, , S. Kuroshima, and O. Zhou, " Silicon and Germanium Clathrates- Gold Inclusion Compounds" , Phys. Rev. B 60, 13245 (1999).

4) Tetsuji Kawaguchi, Katsumi Tanigaki and Masahiro Yasukawa, " Magnetism in Ge- Clathrates with Mn” , Appl. Phys. Lett. 77, 3438 (2000).

5) Katsumi Tanigaki, Tetsuji Kawaguchi and Rudiger Herrmann, “ Doped Si and Ge Clathrates” , Proceed. in Electrochemical Society Meeting, Toronto, Canada, May15- 18, Vo.10, 2000, p.184.

6) Tetsuji Kawaguchi, Katsumi Tanigaki and Masahiro Yasukawa, "Silicon Clathrate with f- Electron System" , Phys. Rev. Lett. 85, 3189 (2000).

7) K. Mizoguchi, A. Sasano, H. Sakamoto, M. Kosaka and K. Tanigaki, "Evidence of 1- D Short Range- Order Below $50 \mathrm{~K}$ in Polymer Phase of Rb1C60", Phys. Rev. B,. 62(12), R7691- R7694 (2000).

8) 谷垣勝己、 $\mathrm{Si}$ および Ge 正1 2面体クラスタ固体における伝導と磁性、日本物理学会誌、56, No.8, 600- 604 (2001).

9) 谷垣勝己、IV 族クラスタ固体の強磁性、応用物理学会薄膜・表面物理分科会 pp.22-28 (2001).

[特許リスト ]

シリコンおよびゲルマニウムクラスレー

卜化合物およびその製造方法 特願 2000-210850 2000.07 .12

磁性クラスレート化合物および光の製＼cjkstart特願２001- $186266 \quad 2001.06 .27$

造方法

[賞]

2000 年大阪科学賞：IV 族クラスタ固体の伝導と磁性 